\title{
Öğrencilerin Zorbalık Davranışı Eğilimlerinin Spora Katılım Açısından İncelenmesi*
}

\section{Investigation of Students' Bullying Behavior in Terms of Sport Participation}

\author{
ORİJINAL ARAŞTIRMA/ \\ ORIGINAL RESEARCH
}

\author{
Mehmet ASMA $^{1 \dagger}$ \\ Nimet GÜRSEL ${ }^{2}$ \\ Hatice ÇAMLIYER ${ }^{3}$
}

${ }^{1} \mathrm{MCBÜ,}$, Spor Bilimleri

Fakültesi, Manisa.

https://orcid.org/0000-0001-

8111-3338

${ }^{2}$ MCBÜ, Spor Bilimleri

Fakültesi, Manisa.

https://orcid.org/000-0001-

9766-1662

${ }^{3}$ MCBÜ, Spor Bilimleri

Fakültesi, Manisa.

https://orcid.org/0000-0003-

1255-875X

\section{Yayın Bilgisi}

Gönderi Tarihi: 25.10 .2018

Kabul Tarihi: 24.05.2019

Online Yayın Tarihi: 30.06.2019

\section{$\ddot{O} z$}

Günümüzde okullarda artan bir problem olarak görülen zorbalık "bir veya birden çok öğrencinin, kendilerinden daha güçsüz öğrencileri, kasıtlı ve sürekli olarak rahatsız etmesiyle sonuçlanan ve öğrencinin kendisini koruyamayacak durumda olduğu bir saldırganlık türü” olarak tanımlanmaktadır. Çocukların bütünsel gelişiminde önemli bir araç olarak görülen spora katılımın zorbalık davranışları üzerinde bir etkisinin olup olmadığı incelenmelidir. $\mathrm{Bu}$ düşünceden hareketle, bu araştırmada ortaokul öğrencilerinin zorbalık davranış eğilimlerinin spora katılım açısından incelenmesi amaçlanmıştır. Araştırma nicel araştırma yöntemlerinden betimleyici nitelikli tarama modelinde gerçekleştirilmiştir. Verilerin elde edilmesinde, olasılıklı olmayan örnekleme yöntemlerinden amaçlı örnekleme yöntemi kullanılmıştır. Katılımcılar Manisa'da 6. 7. 8. sınıflarda öğrenim gören 300 ortaokul öğrencisidir. Veri toplama aracı olarak Satan (2006) tarafindan geliştirilen Zorbalık Davranış Eğilim Ölçeği (ZDEÖ) kullanılmıştır. Veri analizinde bağımsız örneklemler t-testi ve tek yönlü varyans analizi test teknikleri kullanılmıştır. Sonuçlar, spor yapmayan öğrencilerin ölçeğin bütününe ait zorbalık puan ortalamalarının spor yapanlara göre anlamlı düzeyde yüksek olduğunu göstermektedir. Benzer şekilde, verilerin cinsiyet değişkenine göre analizinde, spor yapmayan kızların ölçeğin bütününe ait zorbalık puan ortalamalarının spor yapan kızlara göre anlamlı düzeyde yüksek olduğu tespit edilmiştir. Sınıf değişkenine göre verilerin analizinde, 6 ve 8 . sınıfların duygu zorbalığı alt boyutu dışında ölçeğin tüm alt boyutlarında ve ölçek puan ortalamasında spor yapmayanların zorbalık puanlarının anlamlı düzeyde yüksek olduğu görülmüştür. Bu araştırmadan elde edilen sonuçlara dayalı olarak, öğrencilerin spor faaliyetlerine düzenli olarak katılımının, akran zorbalığı gibi istenmeyen davranışların azaltılmasında etkili olabileceği düşünülmektedir.

Anahtar Kelimeler: Akran zorbalığı, Spor, Ortaokul

\begin{abstract}
Bullying, which is seen as an increasing problem in schools today, is defined as "a type of aggression resulting in deliberate and constant disturbance in which one person or a group of people against others who are less powerful and unable to defend themselves. Participation in sport activities which is seen as an important tool in the holistic development of children, is an important issue that needs to be examined whether it has an impact on bullying behaviours. With this in mind, it was aimed to examine the bullying behaviour tendencies of secondary school students in terms of participation to the sport. The research was carried out with descriptive survey model. Purposeful sampling method was used for obtaining data from non-probabilistic sampling methods. Participants are 300 middle school 6th, 7th and 8th grade students in Manisa. Bullying Behaviour Tendency Scale (BBTC) developed by Satan (2006) was used as data collection tool. Independent samples t-test and one-way analysis of variance were used for data analysis. The results showed that the bullying average points of the students who not participate sport were significantly higher than the licensed sport participants. Similarly, the analysis of the data according to gender variable showed that the total score average of the girls who not participate sports is significantly higher than the girls who participate sportive activities regularly. As indicated by the results of this study, encouraging students to sportive activities is thought to be effective in reducing unwanted behaviours such as peer bullying.
\end{abstract}

Keywords: Peer Bullying, Sports, Secondary School

\footnotetext{
* Bu çalışma 31 Ekim - 3 Kasım 2017 tarihleri arasında Antalya'da düzenlenen Uluslararası Spor Bilimleri Kongresi'nde sözel bildiri olarak sunulmuştur.

† Sorumlu yazar: Mehmet Asma, mehmet.asma@bayar.edu.tr
} 


\section{GíRiş}

Toplumsal bir varlık olan insan, yaşamının her döneminde temel fizyolojik ihtiyaçlarını karşılama, kendini güvende hissetme, kişilerarası etkili iletişim kurma, bir gruba ait olma, sevme, sevilen ve saygı duyulan bir birey olarak hayatını idame ettirme ve kendini gerçekleştirme gereksinimi hisseder (Kılıç, 2009). Bu bağlamda çocukluk ile yetişkinlik arasında bir geçiş süreci olan ve insan gelişimi açısından kritik öneme sahip olan ergenlik dönemi, bireyin sağlıklı bir şekilde topluma uyum sağlaması açısından oldukça önemlidir. Dünya Sağlık Örgütü (WHO, 2014) tarafından 10-19 yaş grubu ergenlik dönemi olarak tanımlanmaktadır. Bireylerin temel eğitim sürecine denk gelen bu dönemde, ergenlerin davranışlarının odaklandığı önemli alanlardan birisi arkadaş ve akranlarıyla olan ilişkileridir. Bu dönemde, gençler ebeveynlerinden özerklik kazanmaya başladıkça, akran grupları daha da önem kazanmaktadır (Brown ve Larson, 2009). Akran grupları, ergenlerin kişisel güvenlerini kazanmalarında ve değerlerin öğretilmesinde ailelerden daha başarılıdır. Ergen; grup ortamında güç, aidiyet ve güven kazanmaktadır. Akran grupları çoğu ergen için tutum ve davranışlarının onaylanmasının ve reddedilmesinin kaynağı durumundadır (Demir, Baran ve Ulusoy, 2005).

Araştırmalar, günümüzde ergenlik döneminde zorbaca davranışların sıklıkla sergilendiğini (Hymel ve Swearer, 2015; K1lı̧, 2009; Yeager, Fong, Lee ve Espelage, 2015), özellikle okul ortamlarında çokça sergilenen bu tarz davranışların öğrenciler arasındaki önemli iletişim sorunlarından birisi olduğunu ortaya koymaktadır (Hymel ve Swearer, 2015; Nansel ve ark., 2001; Nansel ve ark., 2003; Koç, 2007). Aluede, Adeleke, Omoike ve AfenAkpaida'ya (2008) göre okul zorbalığı, dünya çapında ergenlerin zihinsel ve fiziksel sağlığı açısından ciddi bir tehdit oluşturmaktadır. Pişkin (2005), okullarda gerçekleştirilen çeşitli araştırmalara dayanarak, hem zorba, hem de kurban (Zorbalığa maruz kalan öğrenci) oranlarının \%50’lere vardığını ileri sürmektedir. 2017 tarihli “Öğrencilerin İyi Olma Hali” konulu Avrupa Ekonomik İşbirliği Örgütü (OECD) raporunda (2017), öğrencilerin \%4'ünün ayda en az birkaç kez akranları tarafindan itilme gibi fiziksel zorbalığa, \%11'inin ise yine ayda en az birkaç kez kendileri ile dalga geçilme gibi sözel ve psikolojik zorbalığa maruz kaldığı belirtilmektedir. Okul dışındaki durum da çok farklı değildir. Whitney ve Smith'in (1993) araştırma sonuçları okul dışı, yetişkin kontrolünde olmayan oyun aktivitelerine katılan ortaokul öğrencilerin \%76'sının akran zorbalığı davranışına maruz kaldığını ortaya koymaktadır. 
Teorik açıdan bakıldığında Akran zorbalı̆̆ı, saldırganlı̆̆ın bir alt türü olarak tanımlanmaktadır (Melim ve Oliveir, 2013). Alan yazında saldırgan davranışların kökenini irdeleyen birçok teori mevcuttur. Örneğin, Berkowitz'in (1993) Bilişsel Çalışma teorisine göre medyadaki şiddet, izleyicideki sinirli duyguları açığa çıkarmaktadır. Sosyal-Bilişsel Öğrenme kuramının kurucusu Bandura’ya (1965) göre, bireyin, rol-model olarak aldığı kişi ya da kişilerin şiddet uygulaması, bireyi de aynı yönde şiddet uygulamaya teşvik etmektedir. Bandura, iç ve dış faktörlerin karşılıklı ilişkisine vurgu yapmaktayken Sosyal Etkileşim Teorisini savunan Tedeschi ve Felson (1994) ise bu ilişkiyi uyarıcı-tepki arasındaki bilişsel bağlantı ile açıklamaktadır. Sosyal Bilgi-Ișleme Teorisine göre ise (Huesmann, 1998), erken çocukluk dönemindeki tecrübeler, bireyin beyninde belirli programların (şablonların) oluşmasını sağlamaktadır. Tecrübeler medyadan sağlanıyorsa ve şiddet de içeriyorsa, çocuk bu bilgileri zihninde saklar ve zamanı geldiğinde sinirli davranışlar olarak dışa yansıtır. Zillmann'ın (1983) uyarılma aktarımı kuramına göre ise saldırganlık, daha önceki olaylardan kalan olumsuz uyarımların, daha sonraki ortamlara aktarılmasının sonucu ortaya çıan duygusal bir tepkidir. Tüm bu teorik yaklaşımların ortak yanı ise bireyin çevresi ile ilişkilerinin saldırgan davranışlar üzerinde önemli bir rolü olduğudur.

Kaynağı ne olursa olsun, saldırganlığın bir türü olan akran zorbalığı günümüz ergenleri arasında önemli bir iletişim problemidir. Olweus (1993), okullarda sergilenen akran zorbalığını, bir ya da daha fazla öğrencinin bir başka öğrenciye kasıtlı bir biçimde zarar verme ve rahatsız etme amacıyla sürekli olarak olumsuz eylemlerde bulunması olarak tanımlanmaktadır. Furniss (2000), okul zorbalığını fiziksel ve psikolojik olarak ikiye ayırarak, fiziksel zorbalığın bireye arkadaşları tarafından doğrudan yapıldığını, psikolojik zorbalığın ise dolaylı bir zorbalık türü olduğunu belirtmektedir (Akt: Rigby, 2007). Pace (2001) ise zorbalığı psikolojik ve duygusal zorbalık (Bir kişi hakkında bir dedikodu yayma, bir kişiyi konuşmalardan, faaliyetlerden, oyunlardan dışlama vb.), sözel zorbalık (isim takma, tehdit etme, gözdağı verme vb.) ve fiziksel zorbalık (itme, tekme atma, vurma vb.) olmak üzere üçe ayırmaktadır.

İnsan gelişiminde aileden sonra en önemli faktörlerden biri olan arkadaş çevresinin bireyin zorbalık davranışları üzerindeki etkileri oldukça karmaşıktır. Buna karşın, ABD'de Wang, Iannotti ve Nansel'in (2009) 6-10. sınıflar arasındaki ergenler üzerinde gerçekleştirdiği geniş kapsamlı bir araştırmanın sonuçlarına göre, daha fazla arkadaşa sahip olmak ile daha fazla zorbalık davranışı sergileme arasında anlamlı ilişki bulunmuştur. İlgili literatürde, daha fazla arkadaş sahibi olmanın, 
zorbalığa maruz kalma ile olumsuz yönde ilişkili olduğunu ortaya koyan araştırma sonuçları da mevcuttur (Fox ve Boulton, 2005; Hodges, Boivin, Vitaro ve Bukowski, 1999; Raskauskas ve Stoltz, 2007). Spriggs, Iannotti, Nansel ve Haynie'ye (2007) göre, zorbalık davranışlarını sıklıkla sergileyen ergenlerin sosyal olarak yalıtılmış olma ihtimalleri daha düşüktür. Benzer şekilde, Meland, Rydning, Lobben, Breidablik ve Ekeland'in (2010) Norveçli 11-15 yaş grubu ergen öğrencilerle gerçekleştirdiği araştırmanın sonuçları da zorba öğrencilerin bu tarz davranışlarda bulunmayan akranlarına göre daha fazla arkadaşının olduğu sonucunu ortaya koymuştur. Tüm bu araştırma sonuçlarını, daha çok arkadaşa sahip olmanın zorbalık davranışlarına karşı koruyucu bir rolünün mevcudiyetine rağmen, bu tarz davranışları sergileyen öğrencilerin ise benzer şekilde kalabalık arkadaş gruplarına sahip öğrenciler arasından çıktığı şeklinde yorumlamak mümkündür. Akran zorbalığı olgusuna, maruz kalanlar açısından bakıldığında ise sürekli olarak zorbalığa maruz kalan ergenlerde depresyon (Forster ve ark., 2013; Lindquist, Livingston, Heck ve Machek, 2017), sosyal kaygı (Espelage ve Holt, 2001), yalnızlık (Juvonen ve Graham, 2002), düşük benlik saygısı (Arseneault, Bowes ve Shakoor, 2010) ve intihar düşünceleri (Peter, Taylor ve Campbell, 2016; Russell ve Toomey, 2013) gibi bir çok olumsuz sonuçlar meydana getirmesi açısından riskin büyük olduğu düşünülmektedir.

Tüm türleri ile artan bir tehlike olarak okul ortamlarında mevcut olan zorbalık davranışlarına ilişkin farkındalığın arttırılması gerekmektedir. Gerek zorbalığa maruz kalma gerekse de zorbaca davranışları sergileme açısından çocuk ve gençlerin bu tarz davranışlardan kişilik gelişimleri açısından olumsuz etkilendiği düşünüldüğünde, akran zorbalığı çağımızda etkin şekilde mücadele edilmesi gereken bir olgu olarak karşımızda durmaktadır.

Günümüzde pek çok aile, serbest zamanlarını olumlu şekilde geçirmeleri ve sosyal yönden gelişimlerine katkı sağlamaları amacı ile çocuklarını sportif aktivitelere yönlendirmektedir. Mahoney ve Stattin (2000), ergenler üzerinde gerçekleştirdiği araştırma sonuçlarına dayalı olarak, spor gibi serbest zaman aktivitelerinde doyuma ulaşan çocuk ve gençlerin, akran zorbalığı gibi anti-sosyal davranışları daha az sergileyeceğini ileri sürmektedir. Aytan'a göre (2010) spor etkinliklerine katılım insanların sosyal çevreleri ile etkileşim içine girmelerine katkı sağlamakta, böylece sosyal gelişimlerini desteklemektedir. Eğitim çevrelerince de çocuk ve gençlerin bütünsel gelişimleri açısından oldukça önemli görülen bu tarz aktivitelere sürekli katılımın, okullarda gün 
geçtikçe artan bir sorun olan zorbalık davranışları üzerinde bir etkisinin olup olmadığı incelenmesi gereken bir konudur.

Literatürde spora katılımın zorbalık davranışı üzerine etkilerini inceleyen araştırma sonuçlarının çelişkili sonuçlar ortaya koyduğu görülmektedir. Forbes, Adams-Curtis, Pakalka ve White (2006), sportif aktivitelere düzenli olarak katılan öğrencilerin diğer akranlarına göre daha az zorbalık davranışı gösterdiği görüşündedir. Literatürde benzer sonuçlar ortaya koyan araştırmalar mevcuttur (Eccles, Barber, Stone ve Hunt, 2005; Tonts, 2005; Vertommen ve ark., 2016). İlgili alan yazında, aksi yönde ve bu sosyal olguya spor ortamlarında daha sık rastlanıldığı, bu nedenle gençlerin tehlike altında olduğunu ortaya koyan araştırmalar da mevcuttur (Evans, Adler, MacDonald ve Cote, 2016; Peguero, 2008; Shannon, 2013; Symons, Sbaraglia, Hillier ve Mitchell, 2010; Volk ve Lagzdins, 2009). Örneğin, Collot D'Escury ve Dudink'in (2010) gerçekleştirdiği araştırmada, seçilen futbol ve judo programlarındaki çocuk örnekleminin yüzde 26 'sının çeşitli zorbalık biçimleriyle sıklıkla karşılaştı̆̆ sonucuna ulaşılmıştır. Collot D'Escury ve Dudink (2010) gerçekleştirdikleri araştırmanın sonuçlarına dayalı olarak, takım ortamlarında özellikle düşük sportif beceriye sahip çocukların diğer arkadaşları tarafından zorbalığa maruz kaldığı, bunun da çoğunlukla sporu bırakma ile sonuçlandığını ileri sürmektedir. Jachyna'ya (2013) göre, bu tarz davranışların spor kulüplerinde en yaygın olarak sergilendiği yer yetişkin denetiminden uzak olan soyunma odalarıdır. Volk ve Lagzdins'e (2009) göre, kadın ergen sporcular, yaşıtlarına göre daha çok akran zorbalığı eyleminde bulunmaktadır. Çelik, Kurtipek ve İlhan'ın (2016) okul dışı sportif aktivitelere katılan öğrenciler üzerinde gerçekleştirdiği bir başka araştırmanın sonuçları, bu öğrencilerin akranlarına göre zorbalık davranışlarını sergilemeye daha yatkın oldukları sonucunu ortaya koymuştur. Evans ve ark.'na (2016) göre, erkek antrenörlerin çalıştırdığı erkek takımlarında oynayan sporcular arasında zorbalık eğilimi diğer akranlarına göre yüksektir. Steinfeldt, Vaughan, LaFollette ve Steinfeldt'a (2012) göre ise düşük ahlaki değerlere sahip arkadaşlarının bulunduğu takımlarda yer alan sporcu öğrenciler zorbalık davranışlarını sergilemeye daha yatkındır. Öz, Kırımoğlu ve Temiz'in (2011) spor yapan ve yapmayan ortaokul öğrencilerinin üzerinde gerçekleştirdiği benzer bir araştırmada ise gruplar arasında zorbalık eğilimleri açısından anlamlı bir fark elde edilmemiştir. Melim ve Oliveira'ya (2013) göre ise lisanslı olarak spor yapan öğrenciler, okul ortamlarında akranlarına göre zorbalık davranışına daha az maruz kalmaktadır. 
Litaratürde yer alan spora katılım ve akran zorbalığı ilişkisini inceleyen kısıtlı sayıdaki araştırmanın sonuçlarının da birbiri ile tutarlı olmadığı görülmektedir. Ülkemizde gerçekleştirilen araştırmaların sonuçları açısından da durum farklı değildir. Yapılan araştırmalar genellikle okul zorbalığ1 üzerine gerçekleştirilirken, çocuk ve ergenlerin gelişimleri açısından oldukça önemli görülen sportif faaliyetlerdeki durumu inceleyen yeterli sayıda araştırma mevcut değildir. $\mathrm{Bu}$ bağlamda spora katılım ve zorbalık davranışları arasındaki ilişkinin daha net olarak ortaya konulabilmesi için çok daha fazla sayıda ve farklı örneklemlerde araştırmaların yapılması gerekmektedir. Bu düşünceden hareketle bu araştırmanın amacı, Manisa örnekleminde farklı spor branşlarında düzenli olarak spor yapan ve her hangi bir spor branşı ile düzenli olarak ilgilenmeyen öğrencilerin zorbalık davranışları açısından karşılaştırmalı olarak incelenmesidir.

\section{YÖNTEM}

\section{Araştırmanın Modeli}

Araştırma, nicel araştırma yöntemlerinden betimleyici nitelikli tarama modelinde gerçekleştirilmiş̧ir. Tarama modeli, var olan durumu olduğu gibi yansıtmayı esas almaktadır (Balc1, 2004). Araştırma örnekleminin belirlenmesinde ise olasılık temelli olmayan, amaçh örnekleme yöntemi seçilmiştir. Bu örneklemenin esası ana kütle içerisinden, gözle tahmin edilerek, bilgi edinmek istenilen özelliği temsil edebilecek birimleri ayırmaktır. Bu yöntemle örneklem seçiminde birimlerin seçilme olasılıkları bilinmediği gibi bu birimlere dayanan istatistik ölçülerin hatalarının da hesaplanması mümkün değildir. Amaçlı örneklemede; örneklemin ana kütleyi temsil etmesi, araştırmacının tarafsızlığına bağlıdır (Yazıcığlu ve Erdoğan, 2007). Bu araştırmada amaçlı örnekleme yönteminin seçilmesinin temel nedeni, araştırmanın temel çıkış noktası olan, katılımcıların spora aktif ve lisanslı olarak katılma ya da katılmama durumlarının net olarak ortaya konulmasıdır. Bu amaçla spor yapanlar kategorisine en az bir yılı aşkın ve lisanslı olarak spor yapanlar; spor yapmayanlar kategorisine ise bu ölçütü karşılamayan ve her hangi bir spor branşı faaliyetlerine düzenli olarak katılmayanlar dâhil edilmiştir.

\section{Araştırma Grubu}

Katılımcılar Manisa il merkezinde yer alan çeşitli okullarda ve 6. 7. 8. sınıflarda öğrenim gören 300 (166 kadın, 134 erkek) ortaokul öğrencisidir. Öğrencilere ait yaş ortalaması 11.8'dir. 
Spor yapmayan katılımcılar Manisa merkezinde yer alan okullarda öğrenim gören öğrencilerdir. Spor yapanlar ise aynı okullarda öğrenimlerine devam eden ve Manisa merkezinde yer alan spor kulüplerinde bir yılın üzerinde bir süredir lisanslı olarak spora devam edenlerdir. Araştırmacılar tarafından oluşturulan ölçütleri (spor yapmayanlar için düzenli olarak bir spora lisanssız olarak devam etme vb.; spor yapanlar için ise bir yıldan daha az bir süredir spora katılma, lisanssız olarak spor yapma vb.) taşımayan öğrencilerden elde edilen veriler araştırmaya dahil edilmemiş̧ir.

\section{Veri Toplama Araçları}

Veri toplama aracı olarak araştırmacılar tarafından geliştirilen kişisel bilgi formu ve Satan (2006) tarafından geliştirilen Zorbalık Davranış Eğilim Ölçeği (ZDEÖ) kullanılmıştır. Kişisel bilgi formunda katılımcıları tanımaya yönelik, yaş, cinsiyet, spor yapıp yapmama vb. durumlara ilişkin sorular yer almaktadır. Araştırmada kullanılan beşli likert tipindeki ZDEÖ ölçeği 67 maddeden oluşmaktadır. Altı ters maddenin yer aldığı ölçekten en fazla 335 en az ise 67 puan alınabilmektedir. Ölçekten alınan puanların yüksekliği zorbalık eğiliminin yüksek olduğuna işaret etmektedir. Satan tarafından, ölçeğin geçerliği için içerik, kapsam, bilinen grup karşılaştırması, kriter ve yapı geçerliği analizleri uygulanmıştır. Yapı geçerliğine ilişkin faktör analizi sonuçlarına göre öz değeri 1'den büyük olan dört faktör (fiziksel, sözel, eğlence amaçl1 ve duygu zorbalığı) altında toplanan maddelerin birlikte toplam varyansın \%40.13'ünü açıkladığı görülmüştür. Ölçeğin orijinal formunun bütününe ait cronbach alpha güvenirlik katsayısı .95’tir. Bu araştırmada ise bu değer .90 olarak tespit edilmiştir.

\section{Verilerin Analizi}

Analiz sürecine geçilmeden önce verilerin normal dağılım gösterip göstermediği Kolmogorov Smirnov normalilik testi ile incelenmiştir. Test sonuçlarına göre, bağımlı değişkenler için tüm gruplarda normal dağılım gözlenmiştir. Bu kapsamda elde edilen verilerin analizi sürecinde; betimleyici istatistik olarak frekans (f), yüzde (\%), ortalama $(\bar{x})$ ve standart sapma (Ss) değerleri ile anlam çıkarıcı istatistik tekniklerinden ikili değişkenler için bağımsız gruplar için ttesti, ikiden fazla değişkenler için Tek Yönlü Varyans Analizi (One Way Anova) ve anlamlı farkın kaynağını tespit etme amacıyla da Tukey HSD testi uygulanmıştır. 
Asma, M., Gürsel, N., ve Çamlıyer, H. (2019). Öğrencilerin zorbalık davranışı eğilimlerinin spora katılım açısından incelenmesi. CBÜ Beden Ĕ̆itimi ve Spor Bilimleri Dergisi, 14 (1), 23-40.

\section{BULGULAR}

Tablo 1. Araştırma Grubu

\begin{tabular}{|c|c|c|c|}
\hline Değişkenler & Kategori & $\mathbf{N}$ & $\%$ \\
\hline \multirow[t]{2}{*}{ Cinsiyet } & Kadın & 166 & 55.3 \\
\hline & Erkek & 134 & 44.7 \\
\hline \multirow{3}{*}{ Sınıf düzeyi } & 6. sinif & 113 & 37.7 \\
\hline & 7. sinif & 114 & 38.0 \\
\hline & 8. sinif & 73 & 24.3 \\
\hline \multirow{2}{*}{ Spor yapıyor mu? } & Evet & 147 & 49.0 \\
\hline & Hayır & 153 & 51.0 \\
\hline \multirow{5}{*}{ Kaç yıldır spor yapıyor? } & Bir y1l & 32 & 10.7 \\
\hline & 2 y1l & 34 & 11.3 \\
\hline & 3 yil & 32 & 10.7 \\
\hline & 4 yıl ve üzeri & 49 & 16.7 \\
\hline & Toplam & 147 & 49.0 \\
\hline \multirow{4}{*}{ Haftalık antrenman günü } & Haftada 3 güne kadar & 55 & 18.3 \\
\hline & Haftada 4 gün & 46 & 15.3 \\
\hline & Haftada 5 gün ve üzeri & 47 & 15.7 \\
\hline & Toplam & 147 & 49.0 \\
\hline \multirow{4}{*}{ Spor Branş1 } & Futbol & 31 & 10.3 \\
\hline & Basketbol & 45 & 15.0 \\
\hline & Voleybol & 47 & 15.7 \\
\hline & Yüzme & 25 & 8.3 \\
\hline
\end{tabular}

Katılımcıların \%55.3'ü kadın, \%44.7'si ise erkektir. 113'ü (\%37.7) altınc1, 114'ü (\%38) yedinci, 73’ü ise (\%24.3) sekizinci sınıfta öğrenimlerine devam etmektedir. Katılımcıların \%49’u bir y1l veya daha fazla bir süredir lisanslı olarak spor yapmaktadır (Tablo1).

Tablo 2. Katılımcıların zorbalık eğilimlerinin spora katılım durumlarına göre analizini içeren t testi sonuçları

\begin{tabular}{|c|c|c|c|c|c|c|c|}
\hline Alt Boyutlar & Spor Durumu & $\mathbf{N}$ & $\overline{\mathrm{x}}$ & Ss & sd & $\mathbf{t}$ & $\mathbf{p}$ \\
\hline \multirow{2}{*}{ Fiziksel Zorbalık } & Evet & 147 & 1.26 & .320 & \multirow{2}{*}{298} & \multirow{2}{*}{9245} & \multirow{2}{*}{.000} \\
\hline & Hayır & 153 & 1.77 & .586 & & & \\
\hline \multirow{2}{*}{ Sözel Zorbalık } & Evet & 147 & 1.42 & .361 & \multirow{2}{*}{298} & \multirow{2}{*}{7.958} & \multirow{2}{*}{.000} \\
\hline & Hayır & 153 & 1.85 & .551 & & & \\
\hline \multirow{2}{*}{ Eğlence Amaçlı Zorbalık } & Evet & 147 & 1.26 & .355 & \multirow{2}{*}{298} & \multirow{2}{*}{6.778} & \multirow[b]{2}{*}{.000} \\
\hline & Hayır & 153 & 1.64 & .584 & & & \\
\hline \multirow{2}{*}{ Duygu Zorbalığ } & Evet & 147 & 2.56 & .470 & \multirow{2}{*}{298} & \multirow{2}{*}{3.401} & \multirow{2}{*}{.001} \\
\hline & Hayır & 153 & 2.75 & .539 & & & \\
\hline \multirow{2}{*}{ Toplam Puan Ortalaması } & Evet & 147 & 154 & .284 & \multirow{2}{*}{298} & \multirow{2}{*}{8.904} & \multirow{2}{*}{.000} \\
\hline & Hayır & 153 & 1,94 & .473 & & & \\
\hline
\end{tabular}

Tablo 2'de yer alan sonuçlar incelendiğinde, tüm alt boyutlarda ve ölçek puan ortalamasına göre düzenli olarak spor yapanların spor yapmayanlara göre zorbalık eğilimi puanlarının anlamlı derecede düşük olduğu görülmektedir. 
Asma, M., Gürsel, N., ve Çamlıyer, H. (2019). Öğrencilerin zorbalık davranı̧̧ı eğilimlerinin spora katılım açısından incelenmesi. CBÜ Beden Eğitimi ve Spor Bilimleri Dergisi, 14 (1), 23-40.

Tablo 3. Katılımcıların zorbalık eğilimlerinin cinsiyet değişkenine göre analizi ( $\mathrm{t}$ testi)

\begin{tabular}{|c|c|c|c|c|c|c|c|c|}
\hline & Cinsiyet & Spor Durumu & $\mathbf{N}$ & $\overline{\mathrm{x}}$ & Ss & sd & $\mathbf{t}$ & $\mathbf{p}$ \\
\hline \multirow{2}{*}{$\begin{array}{l}\text { Fiziksel } \\
\text { Zorbalık }\end{array}$} & Kadın & $\begin{array}{l}\text { Evet } \\
\text { Hayır }\end{array}$ & $\begin{array}{l}84 \\
82\end{array}$ & $\begin{array}{l}1.21 \\
1.70\end{array}$ & $\begin{array}{l}.260 \\
.640\end{array}$ & 164 & 6.595 & .000 \\
\hline & Erkek & $\begin{array}{l}\text { Evet } \\
\text { Hayır }\end{array}$ & $\begin{array}{l}63 \\
71 \\
\end{array}$ & $\begin{array}{l}1.33 \\
1.84 \\
\end{array}$ & $\begin{array}{l}.376 \\
.511 \\
\end{array}$ & 132 & 6.472 & .000 \\
\hline \multirow{2}{*}{ Sözel Zorbalık } & Kadın & $\begin{array}{l}\text { Evet } \\
\text { Hayır }\end{array}$ & $\begin{array}{l}84 \\
82\end{array}$ & $\begin{array}{l}1.36 \\
1.77\end{array}$ & $\begin{array}{l}.291 \\
.562\end{array}$ & 164 & 5.919 & .000 \\
\hline & Erkek & $\begin{array}{l}\text { Evet } \\
\text { Hayır } \\
\end{array}$ & $\begin{array}{l}63 \\
71 \\
\end{array}$ & $\begin{array}{l}1.49 \\
1.94 \\
\end{array}$ & $\begin{array}{l}.428 \\
.528 \\
\end{array}$ & 132 & 5.290 & .000 \\
\hline \multirow{2}{*}{$\begin{array}{l}\text { Eğlence Amaçlı } \\
\text { Zorbalık }\end{array}$} & Kadın & $\begin{array}{l}\text { Evet } \\
\text { Hayır } \\
\end{array}$ & $\begin{array}{l}84 \\
82 \\
\end{array}$ & $\begin{array}{l}1.20 \\
1.57 \\
\end{array}$ & $\begin{array}{l}.266 \\
.597 \\
\end{array}$ & 164 & 5.165 & .000 \\
\hline & Erkek & $\begin{array}{l}\text { Evet } \\
\text { Hayır }\end{array}$ & $\begin{array}{l}63 \\
71 \\
\end{array}$ & $\begin{array}{l}1.35 \\
1.73 \\
\end{array}$ & $\begin{array}{l}.435 \\
.560 \\
\end{array}$ & 132 & 4.360 & .000 \\
\hline \multirow{2}{*}{ Duygu Zorbalığı } & Kadın & $\begin{array}{l}\text { Evet } \\
\text { Hayır }\end{array}$ & $\begin{array}{l}84 \\
82\end{array}$ & $\begin{array}{l}2.66 \\
2.85\end{array}$ & $\begin{array}{l}.454 \\
.568\end{array}$ & 164 & 2.457 & .015 \\
\hline & Erkek & $\begin{array}{l}\text { Evet } \\
\text { Hayır } \\
\end{array}$ & $\begin{array}{l}63 \\
71 \\
\end{array}$ & $\begin{array}{l}2.42 \\
2.64 \\
\end{array}$ & $\begin{array}{l}.460 \\
.482 \\
\end{array}$ & 132 & 2.697 & .008 \\
\hline \multirow{2}{*}{$\begin{array}{l}\text { Toplam Puan } \\
\text { Ortalamas1 }\end{array}$} & Kadın & $\begin{array}{l}\text { Evet } \\
\text { Hayır }\end{array}$ & $\begin{array}{l}84 \\
82\end{array}$ & $\begin{array}{l}1.51 \\
1.90\end{array}$ & $\begin{array}{l}.239 \\
.496\end{array}$ & 164 & 6.492 & .000 \\
\hline & Erkek & $\begin{array}{l}\text { Evet } \\
\text { Hayır }\end{array}$ & $\begin{array}{l}63 \\
71\end{array}$ & $\begin{array}{l}1.58 \\
1.99\end{array}$ & $\begin{array}{l}.333 \\
.442\end{array}$ & 132 & 6.017 & .000 \\
\hline
\end{tabular}

Tablo 3 incelendiğinde, spor yapan kadın ve erkek katılımcıların tüm boyutlarda spor yapmayanlara göre akran zorbalığı eğilimi puanlarının daha düşük olduğu görülmektedir.

Tablo 4. Katılımcıların zorbalık eğilimlerinin sınıf düzeyi değişkenine göre analizi ( $\mathrm{t}$ testi)

\begin{tabular}{|c|c|c|c|c|c|c|c|c|}
\hline Alt Boyut & Sinif & Spor Durumu & $\mathbf{N}$ & $\bar{x}$ & Ss & sd & $\mathbf{t}$ & $\mathbf{p}$ \\
\hline \multirow{6}{*}{ Fiziksel Zorbalık } & \multirow[t]{2}{*}{ 6. Sinif } & Evet & 68 & 1.28 & .354 & \multirow{2}{*}{111} & \multirow{2}{*}{3.214} & \multirow{2}{*}{.002} \\
\hline & & Hayır & 45 & 1.56 & .566 & & & \\
\hline & \multirow{2}{*}{ 7. Sinit } & Evet & 62 & 1.23 & .261 & \multirow{2}{*}{112} & \multirow{2}{*}{6.998} & \multirow{2}{*}{.000} \\
\hline & & Hayır & 52 & 1.79 & .555 & & & \\
\hline & \multirow{2}{*}{ 8. Sinif } & Evet & 17 & 1.27 & .380 & \multirow{2}{*}{71} & \multirow{2}{*}{4.201} & \multirow{2}{*}{.000} \\
\hline & & Hayır & 56 & 1.91 & .590 & & & \\
\hline \multirow{6}{*}{ Sözel Zorbalık } & \multirow[t]{2}{*}{ 6. Sinif } & Evet & 68 & 1.43 & 399 & 111 & \multirow{2}{*}{2.792} & \multirow{2}{*}{.006} \\
\hline & & Hayır & 45 & 1.67 & .536 & & & \\
\hline & 7. Sinif & Evet & 62 & 1.40 & .305 & & \multirow{2}{*}{5.563} & \multirow{2}{*}{.000} \\
\hline & & Hayır & 52 & 1.84 & .518 & 112 & & \\
\hline & \multirow{2}{*}{ 8. Sinif } & Evet & 17 & 1.45 & .403 & \multirow{2}{*}{71} & \multirow{2}{*}{3.795} & \multirow{2}{*}{.000} \\
\hline & & Hayır & 56 & 2.00 & .558 & & & \\
\hline \multirow{6}{*}{$\begin{array}{l}\text { Eğlence Amaçlı } \\
\text { Zorbalık }\end{array}$} & \multirow{2}{*}{ 6. Sinif } & Evet & 68 & 1.30 & .389 & \multirow{2}{*}{111} & \multirow{2}{*}{2.121} & \multirow[b]{2}{*}{.036} \\
\hline & & Hayır & 45 & 1.48 & .506 & & & \\
\hline & \multirow[t]{2}{*}{ 7. Sinif } & Evet & 62 & 1.21 & .307 & \multirow{2}{*}{112} & & \\
\hline & & Hayır & 52 & 1.65 & .630 & & 4.905 & .000 \\
\hline & 8. Sinif & Evet & 17 & 1.29 & .373 & & & \\
\hline & & Hayır & 56 & 1.76 & .578 & 11 & $3.1 / 1$ & .002 \\
\hline & 6. Sinif & Evet & 68 & 2.51 & .503 & 111 & 1573 & 110 \\
\hline & & Hayır & 45 & 2.67 & .503 & 111 & $1.5 / 3$ & .119 \\
\hline & 7. Sinif & Evet & 62 & 2.59 & .421 & & & 025 \\
\hline Duygu Zorbalığı & & Hayır & 52 & 2.81 & .625 & 112 & 2.273 & .025 \\
\hline & 8. Sinif & Evet & 17 & 2.59 & .517 & 71 & 1300 & 105 \\
\hline & & Hayır & 56 & 2.77 & .477 & 71 & 1.509 & .195 \\
\hline
\end{tabular}


Tablo 4. Katılımcıların zorbalık eğilimlerinin sınıf düzeyi değişkenine göre analizi (devamı)

\begin{tabular}{|c|c|c|c|c|c|c|c|c|}
\hline & Sinif & Spor Durumu & $\mathbf{N}$ & $\bar{x}$ & Ss & sd & $\mathbf{t}$ & $\mathbf{p}$ \\
\hline \multirow{6}{*}{$\begin{array}{l}\text { Toplam Puan } \\
\text { Ortalamas1 }\end{array}$} & 6. Sinif & Evet & 68 & 1.55 & .312 & \multirow[b]{2}{*}{111} & \multirow{2}{*}{3.155} & \multirow[b]{2}{*}{.002} \\
\hline & & Hayır & 45 & 1.78 & .451 & & & \\
\hline & \multirow[t]{2}{*}{ 7. Sinif } & Evet & 62 & 1.52 & .231 & \multirow{2}{*}{112} & \multirow{2}{*}{6.418} & \multirow{2}{*}{.000} \\
\hline & & Hayır & 52 & 1.96 & .473 & & & \\
\hline & \multirow[t]{2}{*}{ 8. Sinif } & Evet & 17 & 1.57 & .351 & \multirow{2}{*}{71} & \multirow{2}{*}{4.114} & \multirow{2}{*}{.000} \\
\hline & & Hayır & 56 & 2.06 & .459 & & & \\
\hline
\end{tabular}

Tablo 4'te yer alan sonuçlar incelendiğinde, 6 ve 8 . sınıfların duygu zorbalığı alt boyutu haricinde, ölçeğin tüm alt boyutlarında ve toplam puan ortalamasında, spor yapan öğrencilerin akran zorbalı̆̆g eğilimi puanlarının düzenli olarak spor yapmayan akranlarına göre istatistiksel açıdan anlamlı düzeyde düşük olduğu görülmektedir.

Tablo 5. Sporcu katılımcıların zorbalık davranış eğilim ölçeği puanların antrenman gün sayısına göre analizini içeren Tek Yönlü Anova testi sonuçları

\begin{tabular}{|c|c|c|c|c|c|c|c|c|c|c|c|}
\hline Alt B. & Gruplar & $\mathbf{N}$ & $\mathbf{X}$ & Ss & Vary. Kay. & KT & Sd & KO & $\mathbf{F}$ & $\mathbf{p}$ & Fark \\
\hline $\begin{array}{l}\text { Fiziksel } \\
\text { Zorb. }\end{array}$ & $\begin{array}{l}\text { 1. Üç gün } \\
\text { 2. Dört gün } \\
\text { 3. Beş ve ü }\end{array}$ & $\begin{array}{l}55 \\
46 \\
47\end{array}$ & $\begin{array}{l}1.20 \\
1.22 \\
1.38\end{array}$ & $\begin{array}{l}.24 \\
.34 \\
.37\end{array}$ & $\begin{array}{l}\text { Gruplarar } \\
\text { Grupiçi } \\
\text { Toplam }\end{array}$ & $\begin{array}{r}.976 \\
14.427 \\
15.403 \\
\end{array}$ & $\begin{array}{r}2 \\
145 \\
147\end{array}$ & $\begin{array}{l}.488 \\
.099\end{array}$ & 4.904 & .009 & $\begin{array}{l}1-3 \\
2-3\end{array}$ \\
\hline $\begin{array}{l}\text { Sözel } \\
\text { Zorb. }\end{array}$ & $\begin{array}{l}\text { 1. Üç gün } \\
\text { 2. Dört gün } \\
\text { 3. Beş ve ü }\end{array}$ & $\begin{array}{l}55 \\
46 \\
47 \\
\end{array}$ & $\begin{array}{l}1.33 \\
1.41 \\
1.54 \\
\end{array}$ & $\begin{array}{l}.27 \\
.42 \\
.36 \\
\end{array}$ & $\begin{array}{l}\text { Gruplarar } \\
\text { Grupiçi } \\
\text { Toplam }\end{array}$ & $\begin{array}{r}1.189 \\
17.894 \\
19.083 \\
\end{array}$ & $\begin{array}{r}2 \\
145 \\
147 \\
\end{array}$ & $\begin{array}{l}.594 \\
.123\end{array}$ & 4.416 & .009 & $1-3$ \\
\hline $\begin{array}{l}\text { Eğlen. } \\
\text { Amaçlı } \\
\text { Zorb. }\end{array}$ & $\begin{array}{l}\text { 1. Üç gün } \\
\text { 2. Dört gün } \\
\text { 3. Beş ve ü }\end{array}$ & $\begin{array}{l}55 \\
46 \\
47 \\
\end{array}$ & $\begin{array}{l}1.16 \\
1.26 \\
1.39 \\
\end{array}$ & $\begin{array}{l}.18 \\
.44 \\
.38 \\
\end{array}$ & $\begin{array}{l}\text { Gruplarar } \\
\text { Grupiçi } \\
\text { Toplam }\end{array}$ & $\begin{array}{r}1.328 \\
17.147 \\
19.083 \\
\end{array}$ & $\begin{array}{r}2 \\
145 \\
147 \\
\end{array}$ & $\begin{array}{l}.664 \\
.118\end{array}$ & 5.614 & .004 & $1-3$ \\
\hline $\begin{array}{l}\text { Duygu } \\
\text { Zorb. }\end{array}$ & $\begin{array}{l}\text { 1. ÜÇ gün } \\
\text { 2. Dört gün } \\
\text { 3. Beş ve ü }\end{array}$ & $\begin{array}{l}55 \\
46 \\
47 \\
\end{array}$ & $\begin{array}{l}2.65 \\
2.52 \\
2.49 \\
\end{array}$ & $\begin{array}{l}.50 \\
.53 \\
.48 \\
\end{array}$ & $\begin{array}{l}\text { Gruplarar } \\
\text { Grupiçi } \\
\text { Toplam }\end{array}$ & $\begin{array}{r}.735 \\
31.596 \\
32.331 \\
\end{array}$ & $\begin{array}{r}2 \\
145 \\
147 \\
\end{array}$ & $\begin{array}{l}.367 \\
.218\end{array}$ & 1.686 & .189 & \\
\hline $\begin{array}{l}\text { Toplam } \\
\text { Puan } \\
\text { Ort. }\end{array}$ & $\begin{array}{l}\text { 1. Üç gün } \\
\text { 2. Dört gün } \\
\text { 3. Beş ve ü }\end{array}$ & $\begin{array}{l}55 \\
46 \\
47\end{array}$ & $\begin{array}{l}149 \\
1.52 \\
1.63\end{array}$ & $\begin{array}{l}2.0 \\
.33 \\
.31\end{array}$ & $\begin{array}{l}\text { Gruplarar } \\
\text { Grupiçi } \\
\text { Toplam }\end{array}$ & $\begin{array}{r}.540 \\
11.387 \\
11.928\end{array}$ & $\begin{array}{c}2 \\
145 \\
147\end{array}$ & $\begin{array}{l}.270 \\
.079\end{array}$ & 3.441 & .035 & $1-3$ \\
\hline
\end{tabular}

Tablo 5'te yer alan gruplar arasındaki farkın kaynağını tespit etme amaciyla gerçekleştirilen Tukey HSD testi sonuçları; fiziksel boyutta farkın, haftada 3 ve 4 gün spor yapanlar ile haftada beş ve üzeri gün spor yapanlar arasında olduğunu göstermektedir. Sözel, eğlence amaçlı ve toplam puan ortalamasında ise fark haftada üç gün spor yapanlar ile 5 gün ve üzeri spor yapanlar arasında ve 5 gün spor yapanlar lehinedir. Grupların akran zorbalığı puan ortalamaları incelendiğinde, genel anlamda duygu zorbalığı dışındaki tüm alt boyutlarda ve ölçek toplam puanında antrenman gün sayısı arttıkça akran zorbalığı eğiliminde de bir artış gözlenmektedir. 
Asma, M., Gürsel, N., ve Çamlıyer, H. (2019). Öğrencilerin zorbalık davranışı eğilimlerinin spora katılım açısından incelenmesi. CBÜ Beden Ĕ̆itimi ve Spor Bilimleri Dergisi, 14 (1), 23-40.

Tablo 6. Sporcu katılımcıların zorbalık davranış eğilim ölçeği puanların spor türüne göre analizini içeren Tek Yönlü Anova testi sonuçları

\begin{tabular}{|c|c|c|c|c|c|c|c|c|c|c|}
\hline Alt Boyut & Gruplar & $\mathbf{N}$ & $\mathbf{X}$ & Ss & Vary. Kay. & KT & Sd & KO & $\mathbf{F}$ & $\mathbf{p}$ \\
\hline $\begin{array}{l}\text { Fiziksel } \\
\text { Zorbalık }\end{array}$ & $\begin{array}{l}\text { 1. Futbol } \\
\text { 2. Basketbol } \\
\text { 3. Voleybol } \\
\text { 4. Yüzme }\end{array}$ & $\begin{array}{l}31 \\
45 \\
47 \\
25 \\
\end{array}$ & $\begin{array}{l}1.28 \\
1.34 \\
1.23 \\
1.18 \\
\end{array}$ & $\begin{array}{l}.31 \\
.40 \\
.31 \\
.16 \\
\end{array}$ & $\begin{array}{l}\text { Gruplarar. } \\
\text { Grupiçi } \\
\text { Toplam }\end{array}$ & $\begin{array}{r}.487 \\
14.916 \\
15.403\end{array}$ & $\begin{array}{r}3 \\
144 \\
147\end{array}$ & $\begin{array}{l}.162 \\
.104\end{array}$ & 1.567 & .200 \\
\hline $\begin{array}{l}\text { Sözel } \\
\text { Zorbalık }\end{array}$ & $\begin{array}{l}\text { 1. Futbol } \\
\text { 2. Basketbol } \\
\text { 3. Voleybol } \\
\text { 4. Yüzme. }\end{array}$ & $\begin{array}{l}31 \\
45 \\
47 \\
25\end{array}$ & $\begin{array}{l}1.39 \\
1.51 \\
1.41 \\
1.31 \\
\end{array}$ & $\begin{array}{l}.38 \\
.43 \\
.31 \\
.25 \\
\end{array}$ & $\begin{array}{l}\text { Gruplarar. } \\
\text { Grupiçi } \\
\text { Toplam }\end{array}$ & $\begin{array}{r}.313 \\
18.162 \\
18.474\end{array}$ & $\begin{array}{r}3 \\
144 \\
147\end{array}$ & $\begin{array}{l}.212 \\
.128\end{array}$ & 1.654 & .180 \\
\hline $\begin{array}{l}\text { Eğlenme } \\
\text { Amaçlı } \\
\text { zorbalık }\end{array}$ & $\begin{array}{l}\text { 1. Futbol } \\
\text { 2. Basketbol } \\
\text { 3. Voleybol } \\
\text { 4. Yüzme. }\end{array}$ & $\begin{array}{l}31 \\
45 \\
47 \\
25\end{array}$ & $\begin{array}{l}1.26 \\
1.33 \\
1.21 \\
1.25 \\
\end{array}$ & $\begin{array}{l}.23 \\
.49 \\
.30 \\
.36 \\
\end{array}$ & $\begin{array}{l}\text { Gruplarar. } \\
\text { Grupiçi } \\
\text { Toplam }\end{array}$ & $\begin{array}{r}.313 \\
18.162 \\
18.474\end{array}$ & $\begin{array}{r}3 \\
144 \\
147\end{array}$ & $\begin{array}{l}.104 \\
.126\end{array}$ & .826 & .482 \\
\hline $\begin{array}{l}\text { Duygu } \\
\text { Zorbalığ } 1\end{array}$ & $\begin{array}{l}\text { 1. Futbol } \\
\text { 2. Basketbol } \\
\text { 3. Voleybol } \\
\text { 4. Yüzme. }\end{array}$ & $\begin{array}{l}31 \\
45 \\
47 \\
25\end{array}$ & $\begin{array}{l}2.42 \\
2.62 \\
2.61 \\
2.56 \\
\end{array}$ & $\begin{array}{l}.50 \\
.49 \\
.48 \\
47 \\
\end{array}$ & $\begin{array}{l}\text { Gruplarar. } \\
\text { Grupiçi } \\
\text { Toplam }\end{array}$ & $\begin{array}{r}.927 \\
31.405 \\
32.331\end{array}$ & $\begin{array}{r}3 \\
144 \\
147\end{array}$ & $\begin{array}{l}.309 \\
.218\end{array}$ & 1.416 & .240 \\
\hline $\begin{array}{l}\text { Toplam } \\
\text { Puan Ort. }\end{array}$ & $\begin{array}{l}\text { 1. Futbol } \\
\text { 2. Basketbol } \\
\text { 3. Voleybol } \\
\text { 4. Yüzme. }\end{array}$ & $\begin{array}{l}31 \\
45 \\
47 \\
25\end{array}$ & $\begin{array}{l}1.52 \\
1.62 \\
1.53 \\
1.54 \\
\end{array}$ & $\begin{array}{l}24 \\
.35 \\
.28 \\
.19\end{array}$ & $\begin{array}{l}\text { Gruplarar. } \\
\text { Grupiçi } \\
\text { Toplam }\end{array}$ & $\begin{array}{r}.406 \\
11.522 \\
11.928\end{array}$ & $\begin{array}{r}3 \\
144 \\
147\end{array}$ & $\begin{array}{l}.135 \\
.080\end{array}$ & 1.691 & .172 \\
\hline
\end{tabular}

Tablo 6'da yer alan, gruplardan elde edilen verilerin spor türüne göre analizini içeren tek yönlü anova testi sonuçları incelendiğinde, hiçbir alt boyutta ve ölçek toplam puan ortalamasında gruplar arası anlamlı fark olmadı̆̆ı görülmektedir.

\section{TARTIŞMA VE SONUÇ}

Elde edilen sonuçlar, bu araştırma örnekleminde spora katılımın öğrencilerin zorbalık eğilimlerini düşürdüğü görüşünü destekler niteliktedir. Sportif aktivitelere düzenli katılımın çocuk ve gençler için fiziksel, sosyal, duygusal ve psikolojik açıdan birçok faydası bulunmaktadır (Anokye ve ark., 2012). Çocukların özellikle ergenlik döneminde; kötü alışkanlıklardan korunması, enerjilerini doğru kullanması, sosyal gelişimleri ve özgüven duygularının artırması için spora yönlendirilmesi önemlidir. Sportif aktivitelere katılan çocuklar, artan ders yüklerinin ve çalışma tempolarının getirdiği baskıdan bir süreliğine de olsa sıyrılma firsatı bulmaktadır. $\mathrm{Bu}$ araştırma örnekleminden elde edilen sonuçlar da bu görüşü destekler niteliktedir. Elde edilen sonuçlar, akran zorbalığı eğilimleri açısından spora katılan bireylerin, düzenli olarak spor yapmayan akranlarına göre zorbalık davranışları eğiliminin düşük olduğunu ortaya koymaktadır. Literatürde farklı sonuçlara ulaşılan araştırmalar yer alsa da (Çelik ve ark, 2016; Kırımoğlu ve Temiz, 2011; Steinfeldt ve ark., 2012) bu araştırmadan elde edilen sonuçlar, sporun çocuk ve 
gençlerin sosyal gelişimini desteklediği ve akran zorbalığını azalttığını öne süren çeşitli araştırma sonuçları ile örtüşmektedir (Eccles ve ark., 2005; Forbes ve ark., 2006; Tonts, 2005; Vertommen ve ark., 2016). Bu çelişkili sonuçların, araştırmaların gerçekleştirildiği yer, yapılan sporun türü, antrenör yaklaşımları, kültürel unsurlar gibi birçok değişkenden kaynaklanabileceği düşünülmektedir.

Cinsiyet değişkeni açısından sonuçlar değerlendirildiğinde, hem kadınlarda hem de erkeklerde akran zorbalığı açısından spora katılımın olumlu etkilerinin bu araştırma örnekleminde görüldüğg̈nü söylemek mümkündür. Öz ve ark.'nın (2011) ortaokul öğrencilerinin spora katılım ve zorbalık eğilimlerini incelediği araştırmada, bu araştırmadan farklı olarak gruplar arasında anlamlı fark bulunmamıştır. Aynı araştırmada yer alan, spor yapma durumlarına göre zorbalık eğilimlerinin analizinde; ölçeğin olumsuz yansıtma, duygusal paylaşım eksikliği, haklı görme, gücü kullanma, rahatsız olmama alt boyutlarında sporcu erkeklerle sedanter erkekler arasında istatistiksel olarak anlamlı bir farklılık tespit edilmemiştir. Ölçeğin başkalarını üzmek alt boyutunda ise sporcu erkeklerin spor yapmayan akranlarına göre puanlarının düşük olduğu saptanmıştır. Kadın öğrencilerin karşılaştırmasında ise sadece olumsuz yansıtma alt boyutunda spor yapmayanlar lehine fark tespit edilmiştir. Ölçeğin diğer boyutlarında ise gruplar arasında herhangi bir fark tespit edilmemiştir. Forbes ve ark.'nın (2006) araştırma sonuçları ise sportif aktivitelere katılan erkek öğrencilerin katılmayan akranlarına göre zorbalık eğilimlerinin daha yüksek olduğuna işaret etmektedir. Volk ve Lagzdins'e (2009) göre, kadın ergen sporcular, yaşıtlarına göre daha çok akran zorbalığı eyleminde bulunmaktadır. Bu araştırma sonuçları ile literatürdeki bazı araştırma sonuçlarının örtüşmemesinin, örneklem seçimi, yapılan spor türü, kültürel farklılıklar gibi unsurlardan kaynaklanmış olabileceği düşünülmektedir.

Katılımcılardan elde edilen verilerin sınıf düzeyi açısından analizi sonuçlarına göre, spor yapan grubun hemen hemen tüm alt boyutlarda spor yapmayan gruba göre anlamlı düzeyde zorbalık eğilimi skorlarının düşük olduğu anlaşılmışıtır. İlgili alan yazında sınıf düzeyi açısından spora katılım durumlarına göre öğrencilerin analizini içeren bir çalışmaya rastlanılmamıştır. Genelde karşılaştırmalar sınıf düzeyleri arasında yapılmıştır. Benzer şekilde, antrenman yapılan gün sayısı açısından spora katılan öğrencilerin akran zorbalığı eğilimlerini inceleyen bir çalışmaya rastlanılmamıştır. $\mathrm{Bu}$ çalışmada ise araştırmanın genel sonuçları ile çelişen bir sonuç elde edilmiştir. Genel olarak sportif aktivitelere katılan öğrencilerin akran zorbalığı eğilimi 
ortalamalarının spor yapmayan akranlarına göre düşük olmasına rağmen, spora katılım yılı arttıkça zorbalık puan ortalamalarının da arttığı gözlenmiştir. Haftada dört gün ve üzerinde bir antrenman sayısı amatörlüğü aşan ve performans sporuna yönelmiş bir antrenman temposuna işaret etmektedir. Başarı baskısı, hedeflere ulaşma açısından maruz kalınan fiziksel ve psikolojik baskılar gibi unsurların sonuçların bu şekilde oluşmasında etkili olabildiği düşünülmektedir. İlgili alan yazında bu sonucu destekleyen bir takım araştırma sonuçları mevcuttur. Örneğin, Webb'in (1969) yaptığı araştırma sonuçlarına göre, spora katılımdaki süre arttıkça sporda kazanma merkezli bakış açısı artarak fair play anlayışının yerini almaktadır (Akt: Shields, 1995:324). Smith, Mugno ve Feltz'in genç erkek buz hokeyi ve futbol oyuncuları ve Silva'nın 203 lise ve üniversite öğrencisi sporcu üzerinde gerçekleştirdiği araştırmanın sonuçları, spora katılım süresindeki artışa paralel olarak saldırgan davranışlarda da artış görüldüğü tezini destekler niteliktedir (Akt: Bredemeier, 1987:48). Endresen ve Olweus'un (2005:468) güç sporlarına katılan adolesan ve adolesan öncesi gençler üzerinde gerçekleştirdiği araştırmada, spora başlama yaşından itibaren spora katılım süresi arttıkça sporcularda görülen anti-sosyal davranışlarda olumsuz yönde bir artış olduğu sonucuna ulaşılmıştır.

$\mathrm{Bu}$ araştırmadan elde edilen bulgulara göre, biri bireysel diğer üçü takım sporundan gelen sporcuların akran zorbalığı puanları arasında anlamlı bir fark elde edilmemiştir. İlgili literatürde ise doğrudan akran zorbalığı ile ilgili araştırmaya rastlanılmazken, saldırgan davranışlar açısından farklı sonuçların elde edildiği araştırma sonuçları mevcuttur. Koruç ve Bayar (1989) ile Tutkun, Güner, Ağaoğlu ve Soslu'nun (2010) araştırma sonuçlarına göre, bireysel sporlarda mücadele eden sporcular takım sporcularına göre daha fazla saldırgan davranışlar sergilemektedir. Tutkun ve ark.'na, (2010) göre ise amaç yönelimli saldırganlığa bireysel spor dalları ile kıyaslandığında genellikle rakibe fiziksel temasın bulunduğu takım sporlarında daha çok rastlanılması nedeni ile takım sporu oyuncuları anti-sosyal davranışları sergilemeye daha yatkındır.

Spora katılımdan beklenilen en üst düzey faydayı sağlamak, alanında iyi yetişmiş, sorumluluk sahibi ve ahlaklı antrenörler ve destekleyici bir çevre etkileşimi ile ancak mümkündür. Ancak çeşitli araştırma sonuçları spor ortamlarında da akran zorbalığı davranışlarının yaygın olduğunu ortaya koymaktadır. Kimi zaman bu durum çocukları bu aktivitelere katılmaktan bile alıkoymaktadır. Örneğin, Somerset ve Hoare'nin (2018), çocukları spor aktivitelerinden alıkoyan engelleri incelediği araştırmanın sonuçları, bu engellerin en önemlilerinden birisinin bu 
ortamlarında sergilenen akran zorbalı̆̆ı olduğunu ortaya koymuştur. Peguero'nun (2008) okul dış1 sportif aktivitelere katılan lise öğrencileri ile gerçekleştirdiği benzer bir araştırmanın sonuçlarına göre ise bu aktivitelere katılan öğrenciler arasında zorbalık davranışlarının sıklıkla gözlendiği sonucuna ulaşılmıştır. Volk ve Lagzdins'in (2009) okul sporlarına katılan öğrencilerle gerçekleştirdiği araştırmanın sonuçları, bu aktivitelere katılan öğrencilerden, \%30-40’1 düşük ölçekte zorbalığa maruz kaldığını; \% 20-25'i düzenli olarak zorbalıktan mağdur olduğunu; \%15’i ise yoğun bir şekilde (yaklaşık olarak haftada bir kez) zorbalık davranışlarına maruz kaldığını ortaya koymuştur.

O'Connor ve Graber'in (2014) altıncı sınıf öğrencileri ile gerçekleştirdiği araştırmanın sonuçları, öğrencilerin yalnızca spor ortamlarında değil beden eğitimi derslerinde de zorbalık davranışlarına maruz kaldığına işaret etmektedir. Araştırmanın sonuçları, altıncı sınıf ögrencilerinin beden eğitimi derslerinde, ders öncesi ve sonrasında soyunma odalarında zorbalık davranışına sıklıkla maruz kaldığını ve bu davranışlara maruz kalan çocukların bu durumu yetişkinlere ve öğretmenlerine söylemekten çekindikleri sonucunu ortaya koymuştur. Adler'in (2014), okul ve kulüp bağlamında zorbalık davranışlarını incelediği araştırmanın sonuçları ise, okul ortamlarında spor kulüplerine kıyasla daha çok zorbalık davranışı sergilendiğini ortaya koymuştur.

$\mathrm{Bu}$ araştırma sonuçları her ne kadar spora katılım ile akran zorbalığı arasında negatif yönlü bir ilişki olduğuna işaret etse de ilgili literatür bulguları ile karşılaştırıldığında, yalnızca spora katılım ile çocuk ve gençlerin zorbaca davranışlar sergilemesinin ya da bu tarz davranışlara maruz kalmalarının önüne geçileceği düşünülmemelidir. Bu bağlamda antrenörler ve tüm ilgililer spor ortamlarında zorbalığın önlenmesi konusunda hassasiyet göstermelidir. Spor ortamlarındaki çocuk ve gençlerin aralarındaki ilişkilerin ve birbirlerine yaklaşımlarının yetişkinler tarafından iyi analiz edilmesi gerekmektedir. Özellikle genç sporcuları bu tarz olumsuz davranışları sergilemeye yönelttiği düşünülen başarı baskısının sporcular üzerinden alınması gerekmektedir. Sporda kazanmak kadar kaybetmenin de normal bir durum olduğu, bunun da olgunlukla karşılanması gerektiği tüm çocuk ve genç sporculara erken yaşlarda öğretilmelidir. Ebeveynler ise çocukları ile iletişimlerini güçlü tutarak, öncelikle bu tarz davranışların tespit edilmesinde, ardından bunların bertaraf edilmesi hususunda yetkililere destek sağlamalıdır. 
Zorbalık davranışları okul ya da dışında olduğu gibi spor ortamlarında da öğrencileri olumsuz şekilde etkileyebilmektedir. $\mathrm{Bu}$ nedenle, çocukların tüm bu ortamlarda akran zorbalığından koruyacak tedbirlerin etkin şekilde alınması gerekmektedir. Spor alanları, çocuklar için gerek fiziksel gerekse psikolojik açıdan daha güvenli hale getirilmelidir. Helion (2006), beden eğitimi derslerinin akran zorbalığının azaltılması açısından uygun koşullara sahip olduğunu ileri sürmektedir. Bu bağlamda, derslerini çocuk ve gençlerin sağlıklı gelişimini destekleyecek bir formda gerçekleştirmesi ve zorbalık davranışlarına yönelik farkındalık oluşturması açısından beden eğitimi öğretmenlerine önemli görevler düşmektedir.

\section{KAYNAKLAR}

Adler, A.L. (2014). An Examination Into Bullying In The Adolscent Sport Context Master Thesis, Queen's University, School of Kinesiology and Health Studies, Ontario,Canada.

Anokye, N. K., Trueman, P., Green, C., Pavey, T. G. and Taylor, R. S. (2012). Physical activity and health related quality of life. BMC Public Health, 12(624), 1-8.

Aluede, O., Adeleke, F., Omoike, D., \& AfenAkpaida, J. (2008). A review of the extent, nature,characteristics and effects of bullying behaviour in schools. Journal of Instructional Psychology, 35, 151-158.

Arseneault, L., Bowes, L., \& Shakoor, S. (2010). Bullying victimization in youths and mental health problems: "Much ado about nothing?" Psychological Medicine, 40(05), 717-729.

Aytan, G. K. (2010). Ortaöğretim öğrencilerinin sosyalleşmelerinde sporun etkileri. Doktora tezi. Gazi Üniversitesi Eğitim Bilimleri Enstitüsü. Ankara.

Balcı, A. (2004). Sosyal Bilimlerde Araştırma Yöntem, Teknik ve İlkeleri. Ankara: PegemA Yayıncılı.

Bandura, A. (1965). Vicarious Processes: A Case of No-Trial Learning. Advances in experimental social psychology, 2, 1-55.

Berkowitz, L. (1993). Pain and aggression: Some findings and implications. Motivation \& Emotion, 17(3), $277-293$.

Bredemeier, J., Brenda, Weiss, R., Maureen.Shields, L., David., Cooper, A.B., Bruce. (1987). The Relationship Between Children's Legitimacy Judgments and Their Moral Reasoning, Aggression Tendencies,and Sport Involvement, Sociology Of Sport Journal, 4, 48-60.

Brown, B. B., \& Larson, J. (2009). Peer relationships in adolescence. In R. M. Lerner \& L. Steinberg (Eds.), Handbook of adolescent psychology, Vol. 2: Contextual influences on adolescent development (74-103). Hoboken, NJ: John Wiley.

Burnukara, P. ve Uçanok, Z. (2012). İlk ve Orta Ergenlikte Akran Zorbalığı: Gerçekleştiği Yerler ve Baş Etme Yolları. Türk Psikoloji Yazıları, 15 (29), 68-82.

Collot D'Escury, A., \& Dudink, A. (2010). Bullying beyond school: Examining the role of sports. In S. Jimerson, S. Swearer, \& D. Espelage (Eds.), Handbook of bullying in school: An international perspective (pp. 235-248). New York, NY: Routledge.

Çelik, O.B, Kurtipek, S, İlhan, E.L. (2016). Increasing bullying tendency in schools: a research in the context of extracurricular sportive activities. Ovidius University Annals, Series Physical Education \& Sport/Science, Movement \& Health, 16(2),335342. 
Asma, M., Gürsel, N., ve Çamlıyer, H. (2019). Öğrencilerin zorbalık davranışı eğilimlerinin spora katılım açısından incelenmesi. CBÜ Beden Ĕ̆itimi ve Spor Bilimleri Dergisi, 14 (1), 23-40.

Dalbudak, İ., Ramazanoğlu, F., Beyleroğlu, M., Gökyürek, B., ve Okan, İ. (2016). Spor bilimleri fakültesindeki performans sporcusu ve spor yapmayan meslek yüksekokulundaki öğrencilerin duygusal zeka ve saldırganlık düzeylerinin incelenmesi 1sparta örneği. Atatürk Üniversitesi Beden Eğitimi ve Spor Bilimleri Dergisi, 18(4), 51-66.

Demir, N.Ö., Baran, A.G., Ulusoy, D. (2005). Türkiye'de ergenlerin arkadaş-akran grupları ile ilişkileri ve sapmış davranışlar: Ankara örneklemi. Bilig, 32, 83-108.

Eccles, J.S., Barber, B.L., Stone, M., Hunt, J. (2003) Extracurricular Activities and Adolescent development. Journal of Social, $59(4), 865-889$.

Endresen, M., Inger., Olweus, Dan. (2005) Participation in power sports and antisocial involvement in preadolescent and adolescent boys. Journal of Child Psychology and Psychiatry, 46(5), 468-478.

Espelage, D. L., \& Holt, M. K. (2001). Bullying and victimization during early adolescence: Peer Influences and psychosocial correlates. Trauma, 2(2-3), 123-142.

Evans, B., Adler, A., MacDonald, D., \& Cote, J. (2016). Bullying victimization and perpetration among adolescent sport teammates. Pediatric Exercise Science, 28(2), 296-303.

Forbes, G. B., Adams-Curtis, L. E., Pakalka, A. H., \& White, K. B. (2006). Dating aggression sexual coercion, and aggressionsupporting attitudes among college men as a function of participation in aggressive high school sports. Violence Against Women, 12(5), 441-455.

Forster,M., Dyal, S. R., Baezconde-Garbanati, L., Chou, C. P., Soto, D. W., \& Unger, J. B. (2013). Bullying victimization as a mediator of associations between cultural/familial variables,substance use, and depressive symptoms among Hispanic youth. Ethnicity and Health, 18(4), 415-432.

Fox, C. L., \& Boulton, M. J. (2005). The social skills problems of victims of bullying: Self, peer and teacher perceptions. British Journal of Educational Psychology, 75, 313-328.

Furniss, C. (2000). Bullying in schools: It's not a crime - is it? Education and Law, 12(1), 10-29.

Helion, J. G. (1996). If we build it, they will come: Creating an emotionally safe physical education environment. Journal of Physical Education, Recreation \& Dance, 67(6), 40-44.

Hodges, E. V., Boivin, M., Vitaro, F., \& Bukowski, W. M. (1999). The power of friendship:Protection against an escalating cycle of peer victimization. Developmental Psychology, 35, 94-101.

Huesmann, L. R. (1998). The role of social information processing and cognitive schema in the acquisition and maintenance of habitual aggressive behavior (p: 73-109), in "Human Aggression: Theories, Research and Implications For Social Policy" (Ed.Russell G. Geen \& Edward Donnerstein). Academic Press, New York.

Hymel, S., \& Swearer, S. (2015). Four decades of research on school bullying: An introduction. American Psychologist, 70, 293299.

Jachyna, P. (2013). Boy's bodies: Speaking the unspoken. Sport, Education and Society, 18(6), 842-846.

Juvonen, J., \& Graham, S. (2002). Self-views versus peer perceptions of victim status among early adolescents. In J. Juvonen \& S. Graham (Eds.), Peer harassment in school: The plight of the vulnerable and victimized (pp. 105-124). New York, NY: Guilford.

Kazanc1, F., ve İlci, B.H. (2018). İlköğretim İkinci Kademe Öğrencilerinde Spor Yapma Durumlarına Göre Atılganlık ve Akran Zorbalığı Özelliklerinin İncelenmesi, Bitlis İli Örneği, International Journal Mountaineering and Climbing, 1(1), 25-30.

K1lıç, N. (2009). İlköğretim 6, 7, 8. Sinıf öğrencilerinin zorbalık düzeylerinin yordanması (Konya ili Cihanbeyli ilçesi ilçe merkez örneği). Yayınlanmamış Yüksek Lisans Tezi, Gazi Üniversitesi, Ankara.

Koç, M. (2007). Şiddetin ortaya çıkardığı psikolojik travmayla baş etmede sporun işlevselliği. Ahmet Yesevi Üniversitesi Sosyal Bilimler Dergisi, 18, 167-179.

Koruç, Z., ve Bayar, P. (1989). Sporun Kişilik Üzerine Etkileri Araştırma Raporu. Ankara: Gençlik ve Spor Genel Müdürlüğü. 
Asma, M., Gürsel, N., ve Çamlıyer, H. (2019). Öğrencilerin zorbalık davranışı eğilimlerinin spora katılım açısından incelenmesi. CBÜ Beden Ĕ̆itimi ve Spor Bilimleri Dergisi, 14 (1), 23-40.

Kowalski, R. M., \& Limber, S. E. (2007). Electronic bullying among middle school students. Journal of Adolescent Health, 41, 22-30.

Kristensen, S. M., \& Smith, P. K. (2003). The use of coping strategies by Danish children classed as bullies, victims, bully/victims, and not involved, in response to different (hypothetical) types of bullying. Scandinavian Journal of Psychology, 44, 479488.

Lindquist, L. M., Livingston, N. A., Heck, N. C., \& Machek, G. R. (2017). Predicting depressive symptoms at the intersection of attribution and minority stress theories. Journal of Gay \& Lesbian Mental Health, 21(1), 32-50.

Mahoney, J.L., Stattin, H. (2000). Leisure activities and adolescent antisocial behavior: The role of structure and social context. Journal of Adolescence, 23, 113-127.

Meland E, Rydning J.H., Lobben S., Breidablik H.J., Ekeland T.J. (2010). Emotional, self-conceptual, and relational characteristics of bullies and the bullied, Scandinavian Journal of Public Health, 38(4),359-367.

Melim, F., \& Oliveira, B. (2013). Prática desportiva, um meio de prevenção do bullying na escola? Movimento, 19(2), 55-77.

Mermer, F. (2012.). Ortaöğretim öğrencilerinde akran çatışmasının incelenmesi. Hemşirelik Anabilim Dalı Yüksek Lisans Tezi, Gaziantep Üniversitesi Sağlık Bilimleri Enstitüsü, Gaziantep.

Mynard, H., \& Joseph, S. (2000). Development of the multidimensional peer-victimization scale. Aggressive Behavior, 26, 169178.

Nansel, T., Overpeck, M., Pilla, R., Ruan, W., Simon-Mortton, B., \& Scheidt, P. (2001). Bullying behaviors among U.S. youth: Prevalence and association with psychosocial adjustment. Journal of the American Medical Association, 285, $2094-2100$.

Nansel, T. R., Overpeck, M. D., Haynie, D. L., Ruan, W. J., \& Scheidt, P. C. (2003). Relationships between bullying and violence among US youth. (Reprinted). Archives of Pediatric and Adolescent Medicine, 157, 348-353.

O'Connor, J.A., Graber, K.C. (2014). Sixth-Grade Physical Education: An Acculturation of Bullying and Fear, Research Quarterly for Exercise and Sport, 85(3), 398-408.

Olweus, D. (1993). Bullying at school: What we know and what we can do. Malden, MA: Blackwell Publishing.

Öz, A.Ş., Kırımoğlu, H., ve Temiz, A. (2011). İlköğretim II. Kademe Öğrencilerinin Spor Yapma Durumlarına göre Zorbalık Eğilimleri ve Zorbalıkla Baş Etme Tarzlarının Spor ve Özel Eğitim Açılarından İncelenmesi. Selçuk Üniversitesi Beden Ĕ̈itimi ve Spor Bilim Dergisi, 13(2), 237-245.

Pace, B. (2001). Bullying. JAMA, 285(16), 2158-2159. Akt: Gökler, R.(2009). Okullarda Akran Zorbalığı. Uluslararası Insan Bilimleri Dergisi, 6(2), 512-537.

Peguero, A. A. (2008). Bullying victimization and extracurricular activity. Journal of School Violence, 7, 71-87.

Peter, T., Taylor, C., Campbell, C. (2016). "You can't break... when you're already broken": The importance of school climate to suicidality among LGBTQ youth. Journal of Gay \& Lesbian Mental Health, 20(3), 195-213.

Pişkin, M. (2002). Okul zorbalığı: Tanımı, türleri, ilişkili olduğu faktörler ve alınabilecek önlemler. Kuram ve Uygulamada Eğitim Bilimleri, 2(2), 531-562.

Pişkin, M. (2005). Okulda Akran Zorbalığı. Ankara Valiliği İl Milli Eğitim Müdürlüğü Özel Eğitim Rehberlik ve Psikolojik Danışma Hizmetleri Bölümü “Okullarda Şiddet” Paneli. Ankara: 12 Ocak 2005.

Raskauskas, J., \& Stoltz, A. D. (2007). Involvement in traditional and electronic bullying among adolescents. Developmental Psychology, 43, 564-575.

Rigby, K. (2007). Bullying in schools and what to do about it, Melbourne, Australian Council for Education Research.

Russell, S. T., \& Toomey, R. B. (2013). Risk and protective factors for suicidal thoughts among sexual minority youth: Evidence from the Add Health study. Journal of Gay \& Lesbian Mental Health, 17(2), 132-149. 
Asma, M., Gürsel, N., ve Çamlıyer, H. (2019). Öğrencilerin zorbalık davranışı eğilimlerinin spora katılım açısından incelenmesi. CBÜ Beden Ĕ̆itimi ve Spor Bilimleri Dergisi, 14 (1), 23-40.

Satan, A. (2006). İlköğretim ikinci kademe öğrencilerinin zorba davranış ĕgilimlerinin okul türü ve bazı sosyo-demografik değişkenler ile ilişkisi. Yayınlanmamış Doktora Tezi. Marmara Üniversitesi, İstanbul.

Shannon, C., S. (2013). Bullying in recreation and sport settings: Exploring hatred factors, prevention efforts, and intervention strategies. Journal of Park \& Recreation Administration, 31(1), 15-33.

Shields, L.L.,D., Bredemeier, L.J.L., Gardner, D.E., Bastrom, A. (1995) Leadership, Cohesion, and Team Norms Regarding Cheating and Aggression. Sociolocy of Sport Journal, 12, 324-336.

Somerset, S., Hoare, D.J. (2018). Barriers to voluntary participation in sport for children: a systematic review, BMC Pediatrics, $18(1), 47$.

Spriggs, A. L., Iannotti, R. J., Nansel, T. R. \& Haynie, D. L. (2007). Adolescent bullying involvement and perceived family, peer and school relations: Commonalities and differences across race/ethnicity. Journal of Adolescent Health, 41, $283-293$.

Steinfeldt, J. A., Vaughan, E. L., LaFollette, J. R. \& Steinfeldt, M. C. (2012). Bullying among adolescent football players: Role of masculinity and moral atmosphere. Psychology of Men \& Masculinity, 13(4), 340-353.

Symons, C., Sbaraglia, M., Hillier, L., \& Mitchell, A. (2010). Come out to play: The sports experiences of lesbian, gay, bisexual and transgender (LGBT) people in Victoria. Melbourne, Victoria: Victoria University.

Tarhan, Ö. (2015). Sosyal bilgiler öğretmeni adaylarının politik okuryazarlığa ilişkin görüşleri. Akademik Sosyal Araştırmalar Dergisi, 9, 649-669.

Tedeschi, J.T., \& Felson, R.B. (1994). Violence, aggression, \& coercive actions. Washington, DC: American Psychological Association.

Tonts M. (2005). Competitive sport and social capital in rural Australia. Journal of Rural Studies 21, $137-149$.

Tutkun, E., Güner, B. Ç., Ağaoğlu, S. A., \& Soslu, R. (2010). Takım sporları ve bireysel sporlar yapan sporcuların saldırganlık düzeylerinin değerlendirilmesi. Spor ve Performans Araştırmaları Dergisi, 1(1), 23-29.

Vertommen, T., Veldhoven, N., Wouters, K., Kampen, J., Brackenridge, C., Rhind, D., ... Van Den Eede, F. (2016). Interpersonal violence against children in sport in the Netherlands and Belgium. Child Abuse \& Neglect, 51, 223-236.

Volk, A. A., \& Lagzdins, L. (2009). Bullying and victimization among adolescent girl athletes. Athletic Insight, 11(1), $12-25$.

Wang J, Iannotti R.J, Nansel T.R. (2009). School bullying among adolescents in the United States: physical, verbal, relational, and cyber, Journal of Adolescent Health, 45(4),368-75.

Whitney, I., \& Smith, P. K. (1993). A survey of the nature and the extent of bullying in junior,middle, and secondary schools. Educational Research, 35, 3-25.

Yazıcığlu, Y., Erdoğan, S. (2007) SPSS uygulamalı Bilimsel Araştırma Yöntemleri. Detay Yayıncılık, II. Baskı, Ankara.

Yeager, D. S., Fong, C. J., Lee, H. Y., \& Espelage, D. L. (2015). Declines in efficacy of anti-bullying programs among older adolescents: Theory and a three-level meta-analysis. Journal of Applied Developmental Psychology, 37, 36-51.

Zillmann, D. (1988). Cognition-excitation interdependencies in aggressive behavior. Aggressive Behavior 14(1), 51-64. 